\title{
The Role of Trust and Culture in the Lebanese Supply Chain Food Industry
}

\begin{abstract}
Aline AL AM
Department of Management, Faculty of Economics and Business Administration, Lebanese University, Third Branch, Lebanon

Email address:

alinealam@hotmail.com

To cite this article:

Aline AL AM. The Role of Trust and Culture in the Lebanese Supply Chain Food Industry. Journal of Business and Economic Development. Vol. 4, No. 3, 2019, pp. 97-106. doi: 10.11648/j.jbed.20190403.14

Received: January 9, 2019; Accepted: July 25, 2019; Published: September 16, 2019

Abstract: This paper aims to investigate the role of trust and culture in buyer-supplier relationships by exploring the drivers behind the ethical practices in the Lebanese food industry. Based on the literature review, supply chain management, business ethics, trust, culture and link between them and ethics, were identified as key elements in building a deep literature to be compared with what is found in Lebanon. A theoretical structure is shown, representing the role of trust and culture as a moderator between the drivers that are identified and the ethical practices. The research sample included four managers from four different companies distributed across all Lebanon. The data analysis showed that ethics in Lebanon started to play a vital role in the success of the four companies leading as well to customers' loyalty. The findings provided support and new results in implementing ethics in the Lebanese food industry.
\end{abstract}

Keywords: Business Ethics, Trust, Culture, Ethical Practices, Supply Chain Management, Lebanese Food Industry

\section{Introduction}

Latest food crises throughout the world have raised some important ethical and legal concerns for nations and health organizations. While the legal regulations addressing food risks are considerably varied and variously effective, less is known about the ethical treatment of the subject. Ethics is a critical tool to help employees make a distinction between acceptable and unacceptable behavior [1]. Ethical climate is one of the important factors of organizational performance that shape inter-organizational relationships and attitudes of the employees. Hence, it is very important to understand the possible relationships between organization's ethical climate and employees' attitudes [2]. Moreover, moral practices and the correct implementation of principled practices are very significant and necessary for organizational goodwill. It is obvious that in company where morals are applied by employees, they are more content and faithful to the firm than those of an unprincipled one; as well, with a strong moral enforcement, companies can construct long term gainful relations with their stakeholders.

This research intends to gain an understanding whether ethical practices are implemented in the Lebanese food companies along with the role of trust and culture that they play in the application of ethics in the Lebanese food industry. It is very important to do this research because even though there are several studies carried out on ethics in the field of supply chain management, the information on this issue in Lebanon and particularly in the Lebanese food industry is not enough and requires further investigation. The main research question will focus on the impact of trust and culture in implementing ethical practices in the Lebanese food industry, by discovering the following drivers: control tools in the quality of food production, control through new business technology, people oriented organizational culture, organizational and individual values, policies and awards, share of information, direct control, long-term relationships and contracts.

\section{Importance of Trust and Culture in Understanding Ethics in Supply Chain Management}

Business ethics are honorable principles and main beliefs that establish our behavior in the commerce world. It refers to commercial actions, either with other firm houses or with a sole client. As well, business ethics embrace the philosophy 
and principles that lead how individuals perform in the place of work [3]. Furthermore business ethics can be practices in all stages of business, from creation of a concept to its sale. It is important and essential to have a code of ethics for every firm in which the executives must espouse suitable tools to apply the requirements of that code of morals but some studies demonstrate that codes of ethics only have a negligible influence on employees' way of thinking and performance. This can be clarified by employees' lack of knowledge of the existence of codes of ethics in companies.

In order to highlight the importance of implementing ethical practices in the organization we can say that an organization's moral values and culture are necessary to its persona, furthermore ethics and moral behavior are topics which are more and more being spotlighted on the business community nowadays. Especially people are becoming more anxious about what is in reality occurring in business organizations in the name of rivalry, expansion, and productivity. In the meantime, companies are traversing the red zone of principles and moral behaviors, where a rising number of these companies are constantly assessing and evaluating the amoral practices in business organizations universally. It was confirmed empirically that moral practices in business companies assist to generate constructive relationships with other companies and can also set up longterm positive relations with existing and possible future clients.

At the present time, governments and stakeholders in business companies are accentuating on the code of business principles and morals. Furthermore, business ethics executives do not refute the significance of having a code of business ethics fulfilling with by the workers of the companies. Each year, many situations of unethical practices happen in dissimilar companies around the world; that is why, many researchers, investigator, and corporate practitioners are also anxious about the rising number of unethical behaviors happening in firms.

While studying the implementation of ethics in SCM and in the Buyer/Supplier Relationship, we notice that moral concerns are grown to be a basic area in business behavior and research acts in the subject of organizational and supply chain management. Especially, ethical concerns become evident in cases of asymmetric relations across companies (e.g. in terms of authority and reliance). These facts have resulted to amplification in the necessity of establishing moral formations, procedures and performance measures in companies. Moreover, with the increasing role of global activities to many business firms, there is an increase in the ethical dilemmas faced by those in the field of purchasing and supply chain management in the future.

Many definitions of Supply Chain Management (SCM) exist from different literature reviews, whether in management, operations, industry, technology, etc. The SCM is defined as: "The management of a set of connections of relations within a company and among mutually dependent associations and business units including material suppliers, buying, manufacture facilities, logistics, advertising, and linked systems that aid the forward and reverse flow of supplies, services, funds and information from the original manufacturer to end client with the remuneration of adding value, increasing the productivity to the maximum through efficiencies, and attaining customer satisfaction [4]".

With the altering role of the buying functions in many companies and in supply chain management around the world, and the diversity of dissimilar factors impacting the environment in which this purpose is carried out, several important inquiries happen concerning the moral environment in the subject of buying and supply chain management nowadays:

What are the main ethical problems confronted by those operating in the profession? What are the main challenges that are confronted by buying and supply chain management professionals when they attempt to contract with the moral dilemmas bumped into in their occupation?

It should be noted that the company's principles, standards and viewpoints considered in planned, strategic and operational business performance should be in parallel with these prospects and insights. It is needed to note that ethical business performance across companies rely on the activities of workers and their attitudes which in sequence require supporting formation and processes. Companies are mutually dependent and completely accountable together for the moral behavior across companies as known in the marketplace and across communities.

Globalization of business practices has push organizations to prolong their spheres of influence across countries and different land masses where the ethical values and principles tend to some degree to be different to the organization's country of origin. Nevertheless, this is a major challenge to be managed in organizations' ambitions to act and behave ethically in the marketplace and across societies since marketplaces and societies have their own culturally acceptable practices and societal expectations

After exploring in the previous section ethics, its implementation across organizations and its importance in SCM, a deep view in the critical and interesting factors that lead to understand ethics in SC especially in modern times is considered a vital step to conduct in this research. Many factors play an important role in understanding ethics in SC among them, trust, culture, commitment, communication, bribery, corruption, reward power, motivation, political environment, values, legislation, loyalty, morality, satisfaction, etc. The most important one which will be our main focus on, are trust and culture due to their significant impact on understanding more the ethical practices between buyers and suppliers in the food industry in a country like Lebanon. The following paragraphs discusses deeply the trust and culture and the role that they play on the relationship between buyers and suppliers.

Walter Lippman defines culture as the term for what people are interested in, their thoughts, their sculpts, the books they read and the speeches they hear, their table-talk, gossip, arguments, scientific training, the values they realize, the quality of life they esteem [5]. Another definition of 
culture is made by Hofstede; he has defined culture as the collective programming of the mind which distinguishes the members of one group or category of people from another [6]. Below a distinction between the national culture and the organizational culture is explained in details.
As for the national culture, it is the set of norms, behaviors, beliefs and customs that exist within the population inside the nation. The national culture consists of six dimensions as described by Hofstede.

Table 1. The six dimensions of the national culture [6].

\begin{tabular}{ll}
\hline Dimension & Description \\
\hline Power Distance Index & $\begin{array}{l}\text { It expresses the degree to which the less powerful members of a society accept and expect that power is distributed } \\
\text { unequally. } \\
\text { Individualism is when individuals take care only of themselves while collectivism which is the opposite is when } \\
\text { individuals anticipate their relatives or society's members to look after them in exchange of information or valuable } \\
\text { benefits for the advantage of both parties. } \\
\text { Individualism versus Collectivism } \\
\text { Masculinity represents a preference in society for attainment, heroism, boldness while its opposite, the femininity } \\
\text { represents a preference for collaboration, reticence and caring for the weak. } \\
\text { Uncertainty Avoidance Index }\end{array} \quad \begin{array}{l}\text { It expresses the degree to which members of the society feel uncomfortable with vagueness and haziness. } \\
\text { Some societies favor to maintain time-honored traditions and norms while viewing societal change with doubt; } \\
\text { Term Normative Orientation }\end{array}$ \\
$\begin{array}{l}\text { while on the other hand, other societies encourage frugality and efforts in modern education as a way to prepare for } \\
\text { the future. }\end{array}$ \\
Indulgence is where the society lets relatively free satisfaction of basic and natural human drives related to enjoying \\
life and having fun, while restraint is where the society represses enjoyment of needs and regulates it by ways of \\
firm social norms.
\end{tabular}

Suppliers in nations with higher saw national honesty might be seen to will probably hold fast to moral or moral standards and show singular respectability. The nation's standards likewise dissuade unusual supplier conduct. Thusly, purchasers are liable to trust suppliers in nations with higher national honesty.

Social contrasts may influence the wellbeing, steadiness, execution and yield of these connections. The acknowledgment that society matters has essential functional ramifications for administrators and also huge ramifications for hypothesis and global examination techniques. Seeing how diverse societies consider the significance of trust and execution to a purchaser's long term direction may enhance the advancement and the sustainability of purchaser supplier connections [7].

One of the outcomes that was found in the exploration directed by Cannon et al underscored the possibility that trust was imperative in building up a purchaser's long term direction in the nonconformist societies (USA, Anglophone Canada) and collectivist societies (Mexico, Francophone Canada) [8].

For instance, a purchaser from a nonconformist society may attempt to connect with a supplier from a collectivist society keeping in mind the end goal to accomplish enhanced value performance. Be that as it may, on the off chance that this purchaser does not perceive the supplier's varying social values, the purchaser may neglect to detect the chance to achieve its cost situated goal.

Therefore, the individualist buyer might consider implementing a balanced performance/trust-oriented strategy with this collectivist supplier in order to achieve the desired price performance. Besides, it may be more important for buying firms to understand cultural differences when obtaining from suppliers with differing cultural values; buyers frequently find that global sourcing opportunities need seeking the best suppliers consistent with the objectives of the purchasing strategy, many with different cultural values. In addition to this, for individualist cultures, buyers expect suppliers to improve the objective performance of their offering like investing in improvements to delivery, cost, and product performance, and also to participate in trustbuilding activities.

At the end, buying firms from individualist cultures should give special attention to make sure that they don't tie the hands of procurement staff with policies appropriate for individualist cultures but inconsistent with collectivist values. For example, when individualist Americans did business in Francophone Canada, they had a propensity to focus on task attachment and failed to spot the chance to develop the relationship through trust building [9].

This research provided additional insight into how culture influences the development of supply chain strategy; additionally, the study offered guidance about how strategies may need to be refined as they were implemented across cultures. While this model and research were built on sound cross-cultural theory, one could not generalize and rule out that differences were idiosyncratic to the markets studied. Although sampling two collectivist and two individualist cultures boosts generalizability of the findings to other countries, additional research in another country, in particular Lebanon, should be done to increase confidence in the model and its predictions. Moreover, regarding the Lebanese situation, examination of the differences since buyers and suppliers are from different cultures is important.

Table 2. Benefits of Building Trust in Business Relationship.

\begin{tabular}{ll}
\hline Benefits & Source \\
\hline Decrease transaction costs in exchange & Ganessan [10] \\
relationships & Noordewier and al [11] \\
Reduce the risk of opportunistic behavior & Ganessan [10] \\
Increase long-term orientation & Ganessan [10] \\
& Doney and al [12] \\
Willing to make idiosyncratic investments & Ganessan [10] \\
Willing to engage in future business opportunity & Doney and al [12] \\
Facilitate cooperative transaction & (Lui, 1998)Lui [13] \\
\hline
\end{tabular}




\section{Link Between Trust and Ethic}

It has been confirmed that the buyer-supplier relationships collect gains as long as the partners of this relation display a long-term direction.

With the business environment becoming increasingly competitive and turbulent in recent years, ethical challenges have dramatically increased, and people whether buyers or suppliers continue to face a very challenging ethical environment in the route of their work. Trust and ethical issues are factors that have impacts on the relationship between buyers and suppliers. The procedure for creating trust amongst purchasers and suppliers is still dubious and reflects alternate points of view about moral obligations owed [14], despite the fact that this relationship is depicted as an important image for inter-firm collaboration and in creating trust in different markets [15].

Hosmer [16] pointed that the relationship amongst purchaser and supplier which mirrored the association or convergence between monetary interest and moral decisions, was the base for making trust in any business setting. Caldwell and Clapham composed a structure for comprehension the trust relationship as a result of the interceding lens that is utilized as a part of assessing the moral obligations of the mental contract [17].

Untrustworthy business practices can weaken the improvement of trusting, long-term business connections. In addition, dishonest conduct can prompt a negative reputation, considerable fines, and at last diminished deals and benefits. We can conclude that most of the researches see ethical practices as an antecedent of trust in the buyer-supplier relationships.

On the other hand, James A. Hill, Stephanie Eckerd, Darryl Wilson, and Bertie Greer proposed and tested a model that evaluate psychological contract violations between a buyer and a supplier as a mediating variable of the effect of unethical activities on trust within a partnership. The resulting mode [18] represents unethical behavior as an antecedent to a decline in trust, as mediated by the experience of a psychological contract violation.

Furthermore, Thompson and Bunderson found that the violation of the apparent psychological agreement existing among parties was regarded as a killer of trust and a severe ethical breach [19]. For this reason, the writer's outcomes provide the consumer helpful tips about the suppliers' attitude and suggest various ways in which the customer's decisions might be apparent by the suppliers; likewise, it was clear that under specific situations, psychological pact breaches could arbitrate the influence of unethical action on trust, and also the relationship between deceit and goodwill in a prolonged relation. Developed understandings of the function of psychological contracts in buyer-supplier relationships takes long time and possess a high promise for upgrading the quality and activity of temporary business partnerships. It was obvious from the results that the other elements added to sentiments of psychological agreement abuse, and it was managerially vital to get more factors involved. To conclude this section, Hill et al. focused on a negative relationship: when there is an unethical behavior there is less trust and introduce the interesting notion of psychological contract [18].

\section{Link Between Culture and Ethical Practices in Supply Chain Management}

In the global commerce literature, culture is a tool to understand encounters and to control their conduct in their different work environments. Culture is one of the important factors of how individuals think and act.

As indicated by Morgan, understanding associations as societies has two specific strengths: it centers its attention on the representative importance, or persona, of the most rational elements of firm's life, and it shows that associations depend on systems of shared implications and systems of elucidation that make and reproduce these meanings [20].

From one viewpoint, organizational culture can be seen as an essential element in regulating ethics in associations. On the other, it can be viewed as the foundation of corporate morals, to such a point, to the point that sometimes the terms morals and society are disordered.

This way, the answer for a standard issue in business ethics is looked for in corporate culture: creating corporate philosophy would be the best approach to determine the antinomy amongst individual and corporative qualities [21]. The likelihood of pending authoritative cultures from a moral viewpoint thus emerges when investigation of these cultures has confirmed that a large number of the considerations and activities of people in associations are socially affected, that people can act and work as indicated by various guidelines and criteria relying upon the situation, and that socialization forms in associations are typically gone for determining people to fit into a regularizing structure.

A sole culture can be said to exist when the individuals from an association share (and not just give lip service to) certain qualities - which may include ethics - to the point that they work inside the structure of specific standards regardless to the social or geographic setting in which they are found. In similar cases, the literary type in which these mutual qualities are openly stated is not a corporate code of morals a "philosophy" that comprehends the association's objectives as more than simply economic execution.

Outrages and untrustworthy practices sustained in spite of the presentation of codes of ethics and ethics administration programs that should ensure consistence to the codes of ethics. Consequently, there is a need to discover a path round this test; which realized the considered corporate moral ethics. This is relied upon to fixate around on activities as well as concentrating on the ethical nature of the character of the business venture and in addition its representatives [22].

The hypotheses of ethics are generally seen from two points of view: relativist and universality. Relativist ethicists imagine that morals and sound good thinking are nearly 
connected with societies, and in addition singular inclinations which perpetually breed diverse frameworks of morals and ethics which can coincide and remain similarly legitimate. Moral scholars allude to it as 'anything goes' [23]. Widespread ethical scholars, as per Brennan are moral guidelines which are regular crosswise over societies through which the rightness or decency of an activity can be set up.

Nevertheless, constructing and keeping up authoritative honesty requires more than simply passing laws and publicizing notions. Laws and authority rules layout the base level of obligation [24] however these formal benchmarks can't themselves guarantee moral conduct. This being the situation, the associations own particular society has a vital part to play in making and enhancing moral conduct and in concretizing the moral principles of the association.

To conclude this section, it is obvious that there is a link between the business ethics, trust, culture and ethical implementation in the food supply chain management as see from the above literature review.

\section{Application in the Lebanese Food Sector}

The key purpose of the present research was to obtain a deeper understanding of the existence and implementation of ethical or unethical practices in the Lebanese food industry; in order to do this; the chosen strategy of personalized interviews with key personnel presented an effective technique for capturing the necessary data. In the present instance, qualitative work helped to explore the research propositions and how the individuals or participants in a relationship gave meaning to and communicated their understanding of themselves, others and their world. In the end, perception is reality. The qualitative approach made it possible to explore and discuss the implementation of ethical or unethical practices in the Lebanese food industry. Finally, qualitative measures were necessary to deal with the complexities and ambiguities that characterize the relationship between buyers and suppliers, especially when discussed from two different cultural perspectives.

Following the establishment of the research problem and design, the sample for the qualitative research was selected as four Lebanese managers from four Lebanese companies in areas of the food and beverage industry. Different interviews took place with the four managers in order to collect the necessary data and answer the research question. Qualitative research is typically based on small samples, with the purpose of providing insight and deeper consideration of a phenomenon [25]. In the present study, the main questions of the interviews focused on getting a clear picture of the roles played by trust and culture in implementing ethical and unethical practices in the Lebanese food supply chain. The sample was chosen due to the fact that the four Lebanese companies are the biggest companies in Lebanon based on the nature of their size, distribution channels, capital, etc. The table below presents the characteristics of the companies in study.

Table 3. Presentation of the four companies.

\begin{tabular}{|c|c|c|c|c|}
\hline $\begin{array}{l}\text { Name of the } \\
\text { Company }\end{array}$ & Junet & Kallassi & Massabki & Machaalany \\
\hline Size & $\begin{array}{l}\text { Large ( } 215 \text { employees, } \$ 3-4 \\
\text { million as turnover) }\end{array}$ & $\begin{array}{l}\text { Large (400 employees, } \$ 20-25 \\
\text { million as turnover) }\end{array}$ & $\begin{array}{l}\text { Medium ( } 38 \text { employees, up } \\
\text { to } \$ 1 \text { million as turnover) }\end{array}$ & $\begin{array}{l}\text { Large (178 employees, } \$ 6- \\
8 \text { million as turnover) }\end{array}$ \\
\hline $\begin{array}{l}\text { Geographical } \\
\text { Distribution of the } \\
\text { Product }\end{array}$ & $\begin{array}{l}\text { All Lebanese shops, and } \\
\text { around } 38 \text { countries around } \\
\text { the globe }\end{array}$ & $\begin{array}{l}\text { All Lebanese shops and } \\
\text { especially in Syria and Iraq }\end{array}$ & $\begin{array}{l}\text { Bekaa Valley and } \\
\text { someshops in the capital } \\
\text { city only }\end{array}$ & $\begin{array}{l}\text { All Lebanese shops and } \\
\text { around } 35 \text { countries around } \\
\text { the globe }\end{array}$ \\
\hline Age & 1978 & 1977 & 1970 & 1943 \\
\hline $\begin{array}{l}\text { Concentration of the } \\
\text { Supply }\end{array}$ & $\begin{array}{l}\text { Big Suppliers (From overseas } \\
\text { and local) }\end{array}$ & $\begin{array}{l}\text { Big Suppliers (From overseas } \\
\text { and local) }\end{array}$ & $\begin{array}{l}\text { Big Suppliers (From } \\
\text { overseas and local) }\end{array}$ & $\begin{array}{l}\text { Big Suppliers (From } \\
\text { overseas and local) }\end{array}$ \\
\hline $\begin{array}{l}\text { Access to Individual } \\
\text { Customers }\end{array}$ & Direct and Indirect & Direct and Indirect & Direct and Indirect & Direct and Indirect \\
\hline
\end{tabular}

In the present research, four Lebanese managers were nterviewed. They all have a great deal of experience and a deep knowledge of the Lebanese food industry. Additionally, their characters were critical for the success of the research, especially because the topic under discussion required plenty of sensitivity in order to obtain honest and accurate answers. The literature relating to methodology proposes that these considerations are especially needed in gender-related studies and sensitive topics as well as in inductive research, where physical and verbal behaviors are observed.

The table below provides a summary of the drivers, their definitions, their influences in implementing ethical practices, their links with culture and trust and their presence in the four Lebanese companies. 
Table 4. The different drivers in the four companies.

\begin{tabular}{|c|c|}
\hline Driver & Definition \\
\hline $\begin{array}{l}\text { Control tools in } \\
\text { the quality of } \\
\text { food production }\end{array}$ & $\begin{array}{l}\text { Control tools are considered as } \\
\text { devices used in understanding } \\
\text { and improving production } \\
\text { processes; they are regarded as a } \\
\text { set of procedures intended to } \\
\text { ensure that a manufactured } \\
\text { product or performed service } \\
\text { adheres to a defined set of quality } \\
\text { criteria or meets the requirements } \\
\text { of the client or customer. }\end{array}$ \\
\hline $\begin{array}{l}\text { Control through } \\
\text { new business } \\
\text { technologies }\end{array}$ & $\begin{array}{l}\text { Proximity to control through new } \\
\text { business technologies is } \\
\text { underpinned by an ever- } \\
\text { increasing reliance on } \\
\text { information technology by } \\
\text { companies to handle and } \\
\text { optimize their business processes }\end{array}$ \\
\hline
\end{tabular}

How the implementation of ethical
practices is driven
Food quality management solutions
enable companies in the food and
beverage industry to capture, route,
correct, prevent, and analyze system-
wide issues between their
organization and their trading
partners, which in turn increases the
implementation of ethical practices.

Ethical issues raised by information systems and new communication technologies include establishing accountability for the consequences of information systems, setting standards to safeguard system quality that protects the safety of the individual and society, and preserving values and institutions considered essential to the quality of life in an information society.

Organizational culture provides a framework through which

People-oriented organizational culture

\section{members internalize expectations} about organizational roles and behaviors and serves to a large extent as an organizational control mechanism.

Values provide the foundation for individual opinions that lead to the development of decision-

Organizational making behaviors; individual

and individual values are enhanced by the values

Policies and Awards

Share of Information organizations or companies since the firms believe that adopting many values support their overall mission, vision and success.

Policies at the national and the organizational (company) level include activities such as regulation of food, establishing eligibility standards for food assistance programs, ensuring safety of the food supply, food labeling. Awards within the companies (given by the companies) help employees take pride in their work and instill confidence in customers about the quality and professionalism of the organization.

Information sharing describes the exchange of data between various organizations, people and technologies.
The managerial practices promote an ethical culture by taking a visible role, communicating ethical expectations, providing ethical training, rewarding ethical acts and punishing unethical ones.

Values that are encouraged on an organizational level could serve as a foundation for understanding ethical practices and work behaviors that affect all stakeholders; individuals can differentiate between ethical and unethical practices through the values that the companies adopt or create within the firms to boost the importance of implementing these ethical actions; companies, through adopting certain values, drive and influence human behavior towards implementing ethical practices within their daily operations both inside and outside the workplace.

Policies are a set of rules and regulations that deal with ethical and unethical practices, legal liabilities, regulatory requirements, etc; awards enhance a company's reputation, help employees take pride in their work, push them more and more to apply ethical practices and instill confidence in customers in relation to the quality and professionalism of the organization.

Information-sharing pushes the implementation of ethical practices since companies can reach a competitive position, increase their

\section{Link with trust/culture}

Present cases

under study

Customers feel more trusting in buying their products; Through the media, the Lebanese companies started to influence and impact the Lebanese culture by creating a certain position in the Lebanese consumers' minds that the firms are applying the best tools in controlling the food quality.

New business technologies increase the circulation of information which engenders trust. Using any up-dated or new software to control the quality of the products, trust will be higher and higher between the companies and the suppliers. It is within the Lebanese culture that the Lebanese companies buy and use the latest equipment, the latest technology to improve their productivity and increase the level of trust, whether with the suppliers or the customers.

Creating a positive and professional culture inside organizations will automatically increase the level of trust, with both customers and suppliers, through delivering the best quality products to the Lebanese marketplace.

Individual values are important factors in building trust, where open internal communication is often characterized by the open sharing of opinions and feedback between different levels of an organization; it is within the Lebanese culture that the more you value someone, the more he or she will be satisfied and trusting.

It is within the culture that individuals and companies apply the national or organizational policies that lead to high quality service, customer satisfaction and also the successful growing of the business. It is within the Lebanese culture that awards offered by the companies are considered as major forces that will motivate both employees and companies.

By sharing information, the level of trust between the suppliers and buyers will increase, since both them believe that this exchange is
Junet, Kallassi,

Massabki,

Machaalany

Kallassi, Machaalany, Junet

Junet, Kallassi, Massabki,

Machaalany

Junet, Kallassi, Massabki, Machaalany

Kallassi,

Massabki, Machaalany, Junet

Junet, Kallassi, Machaalany 


\begin{tabular}{|c|c|c|c|c|}
\hline Driver & Definition & $\begin{array}{l}\text { How the implementation of ethical } \\
\text { practices is driven }\end{array}$ & Link with trust/culture & $\begin{array}{l}\text { Present cases } \\
\text { under study }\end{array}$ \\
\hline & & $\begin{array}{l}\text { efficiency and effectiveness through } \\
\text { the exchange of information. }\end{array}$ & $\begin{array}{l}\text { taking place for their benefit. As } \\
\text { for the culture, companies do not } \\
\text { share any information with each } \\
\text { other, because it is in their culture } \\
\text { not to help each other or give } \\
\text { information that benefits the other } \\
\text { party. }\end{array}$ & \\
\hline Direct contact & $\begin{array}{l}\text { Direct contact is considered as } \\
\text { the direct communication that } \\
\text { takes place between the buyers } \\
\text { and suppliers. }\end{array}$ & $\begin{array}{l}\text { Direct contact provides a clear } \\
\text { understanding of all steps especially } \\
\text { the ones related to ethical practices } \\
\text { without having any third party or } \\
\text { intermediary which may cause noise } \\
\text { through the communication channels. }\end{array}$ & $\begin{array}{l}\text { Direct contact will improve and } \\
\text { give the customers more trust and } \\
\text { confidence and attraction in buying } \\
\text { the products, because the customers } \\
\text { feel that their feedback was taken } \\
\text { into consideration. }\end{array}$ & Junet, Massabki \\
\hline $\begin{array}{l}\text { Long-term } \\
\text { relationship }\end{array}$ & $\begin{array}{l}\text { Long-term relationships are } \\
\text { commitments resulting in } \\
\text { independent channel members } \\
\text { working together to serve } \\
\text { customer needs better and } \\
\text { increase mutual profitability. }\end{array}$ & $\begin{array}{l}\text { This relationship keeps the } \\
\text { implementation of ethical conduct } \\
\text { secure and encourages more and more } \\
\text { the use of ethical practices to } \\
\text { strengthen this relationship and turn it } \\
\text { into a sustainable level of connection } \\
\text { and association. }\end{array}$ & $\begin{array}{l}\text { Extended relationships enhance the } \\
\text { level of mutual trust. As for the } \\
\text { culture, the suppliers always look } \\
\text { for new opportunities, trying to get } \\
\text { better prices by reducing the costs } \\
\text { and increasing their profits. }\end{array}$ & $\begin{array}{l}\text { Junet, Kallassi, } \\
\text { Machaalany, } \\
\text { Massabki }\end{array}$ \\
\hline Contracts & $\begin{array}{l}\text { Contracts are written agreements } \\
\text { stating exactly the rights and } \\
\text { responsibilities of buyers and } \\
\text { suppliers, which oblige both } \\
\text { parties to apply what they agree } \\
\text { on. }\end{array}$ & $\begin{array}{l}\text { Contracts state exactly the rights and } \\
\text { responsibilities of each party, and they } \\
\text { drive each party to apply ethical } \\
\text { practices in all steps to avoid any } \\
\text { breaching of the contract and any } \\
\text { violation or legal actions. }\end{array}$ & $\begin{array}{l}\text { Contracts lead to an increase in } \\
\text { trust among all parties and } \\
\text { especially buyer's trust and his } \\
\text { perception towards the companies. } \\
\text { It is in the culture that some } \\
\text { Lebanese buyers and suppliers do } \\
\text { not respect the points or the clauses } \\
\text { of a contract. }\end{array}$ & $\begin{array}{l}\text { Kallassi, Junet, } \\
\text { Machaalany }\end{array}$ \\
\hline
\end{tabular}

Trust and culture have played a big role on the nine drivers. Trust as it was shown in the literature review offered many benefits in building a strong relationship between buyers and suppliers through the understanding of the behaviors of both parties [17], and in facilitating any engagement in business opportunity in the future. Moreover, trust has impacted the tools to control the quality of food production in influencing the Lebanese companies to include, for instance, honest information to customers through the labels found on the products. In other words, the Lebanese companies believe that through the fact of trusting different tools to control the quality of food production like the governmental standards, work attitudes, food safety, internal audits, it will improve and increase the use of ethical practices in the food industry.

As for the culture, quality practices are adopted by cultural values. However, the management of a company may invest in quality programs as a step in the strategic plan. The Lebanese companies through culture show an open thinking to accept and implement any new tool to control the quality of food production and build a strong position in the consumers' minds enhancing their belief that the companies are applying the best ethical practices in their industries.

Trust has been considered a predictor or an antecedent of cooperative behavior, where it is not only an input to a relationship but a pre-condition to the development of the relationship between buyers and suppliers [26]. This has reflected positively on the Lebanese companies since they control their operations through new business technologies due to the fact that the Lebanese firms trust their suppliers. Additionally, trust has allowed the use of electronic mail, information systems through the use of management and utilization of databases, as well as the protection of any information related to the manufacturing and packaging of products. This trust between the Lebanese companies and their suppliers has pushed the firms to increase their use of technology. These actions convinced customers that the companies are using and applying ethical practices within their industries. Regarding culture, it influenced the control through new business technologies positively due to the fact that within the Lebanese culture, the Lebanese firms buy and use the latest equipment and technology thus increasing the level of trust with the suppliers and the customers and consequently the application of ethical practices in all the conducted steps.

Furthermore, trust and culture have impacted the third driver, the people oriented organizational culture. Inside the organizational culture of the four companies, trust has strengthened the relationship between the four Lebanese managers and their employees. The managers do not keep things away from their employees who, in turn, tell their supervisors or managers anything happening or taking place so that transparency exists and increases the level of trust. Thus, trust is an important element of the four companies' culture affecting the managers' and employees' behaviors, communication and decision making as for the culture.

Culture and organizational culture are linked. Any change in the structure of the firms will stimulate changes in the culture. When Lebanese companies buy new equipment and software to improve their businesses performance, the managers will make some changes in the structure of the organizations by hiring new and well trained employees.

Moving to the fourth driver, trust has facilitated and helped 
managers and employees to value each other where it was shown that when employees feel this value they will automatically improve their open dialogue, honesty, communication, transparency and pay more attention in implementing ethical steps inside the companies. When trust exists between employees and managers, the outcomes will lead to improve quality of products, and deliver values inside the organization which in turn will reflect greater value to customers [27]. It is within the Lebanese culture that the more you value someone, the more he or she will be satisfied and trusting. Trust has affected policies and awards positively. Customers' trust in the company which is considered or defined as customer confidence will improve whenever they see that the firm is implementing policies leading to increased implementation of ethical practices. Trust also facilitates the way policies are implemented. Once employees and managers inside the companies trust each other, they believe that the policies that they follow will be beneficial for both of them. Culture on the other hand, has impacted the policies and awards since there exist a link between the culture and the policy leading to a high quality service by satisfying the customers and growing the companies successfully. Regarding awards, it is believed that within the culture, once a company wins an award, it will increase the customers' level of trust and their perception that the company is implementing ethical practices and therefore improve customers' confidence towards it.

As for the role of trust and culture in sharing information, it was shown that trust is considered a valued provider to many forms of exchange and to supply chain relationships [12]. Since trust between employees and managers and between the four companies and the customers exist, it influenced the share of information positively and smoothly where all parties exchange and communicate necessary information which, in turn, strengthens the relationships among all involved parties. It was shown that shared norms entail that the manufacturer and dealer share the belief that information sharing is important and necessary for the success of any relationship [28]. Additionally, it was shown that when companies hire personnel that bond with their culture, the shared social knowledge will be enhanced and steadiness between the goals of the firms and the employees will increase. As for the culture, it was found that the Lebanese managers do not share any information with other Lebanese managers or other local companies since they are afraid of letting someone take advantage of them.

As for the direct contact, trust influences this driver positively. In other words, since the Lebanese companies trust their suppliers, they contact them directly, leading to a better understanding as well as a reduction in miscommunication or conflict, and also most importantly leading to a better implementation of ethics inside the companies. Since trust exists between the Lebanese companies and their suppliers, any contact made between the two parties will lead to improve the steps of conducting the business, the situation and by in turn, improve the applications of ethical practices. The same scenario is taking place between the Lebanese companies and the Lebanese buyers (shops, supermarkets) where trust has helped both parties to contact each other directly and take any remarks, feedback or suggestions into consideration to improve any ethical practices taking place inside the industries or inside the Lebanese shops. Regarding culture, it was shown that within the Lebanese culture, once the Lebanese companies, their suppliers and their buyers contact directly each other without the presence of third parties, they feel more secure and satisfied and enthusiastic to apply more ethical practices and improve their business practices.

Moving to the long-term relationship, trust has been considered a vital factor in building buyer-supplier relationships [18], added certain continuity in channel relationships [29] and the essential driver in developing longterm relationships [10]. Through trust, the Lebanese companies along with their suppliers and their customers were able to create a long-term relationship which also has facilitated the implementation of ethical practices. Moreover, trust revealed a positive association with relationship satisfaction; hence it is considered a necessity in building and sustaining productive and long term relationships. It was noticed that the four Lebanese companies got positive results and better outcomes due to the role that trust has played in building long-term relationships whether between the Lebanese companies and their suppliers or between them and their customers. It was obvious that trust over a long period of time makes the relationships between the Lebanese companies, suppliers and buyers, strong and deep leading to achieve the objectives. As for the culture, it has impacted the long-term relationship positively and negatively. It is within the Lebanese culture, that even though the four Lebanese companies have deep and strong relationships with their suppliers, they will keep looking for new opportunistic relationships with new suppliers. On the other hand, the four Lebanese companies always work hard to keep their relationships with the buyers successful and sustainable. Moreover, it is not easy for the Lebanese companies to lose any of their customers, since it is inside their culture to keep their existing customers satisfied, and look for new customers to build with them a long-term relationship.

The last driver influenced by trust and culture is the contracts. It was shown that trust between the Lebanese companies and their suppliers has made the contracts like a gentle reminder to respect the due dates and commitment between the parties. Trust also has influenced the contracts in a way that all parties, the Lebanese companies along with their suppliers and buyers, will view it as a beneficial step toward improving any action that increases the implementation of ethical practices. Furthermore, it is within the Lebanese culture, that the four Lebanese companies respect any commitment with their suppliers, while the Lebanese consumers or buyers do not respect any commitment or due dates with the four Lebanese companies, which show that the Lebanese customers do not esteem the value of contracts. 


\section{Conclusion}

The main question in this research was to investigate the drivers that can be found in the Lebanese food industry along with their influences in applying ethics whether inside or outside the companies, and to study the role of trust and culture in implementing ethical practices within different companies.

The context of the present research aimed to enrich the understanding of different drivers behind ethical practices in the Lebanese food industry. In doing so, it employed existing studies of contemporary research methodology and takes clear steps towards gaining insightful evidence, leading to managerial and theoretical contributions. Four Lebanese companies were selected and data were collected based on the qualitative research methodology that was used in this research. The research sample is discussed by highlighting the characteristics of the Lebanese managers of the four companies selected for study, followed by the clarification of the data collection and the qualitative questionnaire, along with the pilot study, the semi-structured interview and the indepth interview; as a result, the construction of the interview framework is explicated along with the tools used for collecting the data.

In brief, it was found that trust and culture play a big role in implementing ethics in the Lebanese food industry, although from time to time, we hear about unethical practices caught in the food industry in different cities and regions. Nine drivers have been identified based on the interviews conducted with four managers in the selected four companies and results were based on collecting and analyzing their answers. Moreover, theoretical and managerial contributions were discussed deeply in order to strengthen the research.

Finally, although the companies are pushing themselves hard to implement ethics within their industries, there still exist different factors that are playing a big role in restricting and hindering the implementation of ethics, among them bribery, economic pressures and high competition in the Lebanese marketplace and around the globe.

\section{References}

[1] Erondu, E. A., Sharland, A., and Okpara, J. O. (2004). Corporate ethics in Nigeria: A test of the concept of an ethical climate. Journal of Business Ethics, 51.

[2] Elçi, M. and Alpkan, L. (2009). The impact of perceived organizational climate on work satisfaction. Journal of Business Ethics, 84.

[3] Ferrell, O. C., Fraedrich, J. and Ferrell, L. (2005). Business Ethics: Ethical Decision-Making and Cases. Boston: Houghton Mifflin Company.

[4] Stock, J. and Boyer, S. (2009). Developing a consensus definition of supply chain management: a qualitative study. International Journal of Physical Distribution and Logistics Management, 39 (8).

[5] www.quotes.net.
[6] Hofstede, G. (1991). Culture and Organizations: Software of the Mind. London: McGraw-Hill.

[7] Ang, S. and Inkpen, A. C. (2008). Cultural intelligence and offshore outsourcing success: a framework of firm-level intercultural capability,. Decision Sciences, 39 (3).

[8] Cannon, J. P., Doney, P. M., Mullen, M. R., and Petersen, K. J. (2010). Building lone-term orientation in buyer-supplier relationships: the moderating role of culture,. Journal of Operations Management, 28.

[9] Rodriguez, C. M., and Wilson, D. T. (2002). Relationship Bonding and Trust as a Foundation for Commitment in USMexican Strategic Alliances: A Structural Equation Modeling Approach. Journal of International Marketing, 10 (4).

[10] Ganessan, S. (1994). Determinants of Long-Term Orientation in Buyer-Seller Relationships. Journal of Marketing, 58 (April).

[11] Noordewier, Thomas G., George John, and John R. Nevin. (1990). Performance Outcomes of Purchasing Arrangements in Industrial Buyer-Vendor Relationships. Journal of Marketing, 54 (October), 80-93.

[12] Doney, P. M., Cannon, J. P., and Mullen, M. R. (1998). Understanding the influence of national culture on the development of trust. Academy of Management Journal, 23 (3).

[13] Lui, T. -1. (1998). Trust and Chinese Business Behaviour. Competition \& Change, 3, 335-57.

[14] Philips, R. and Caldwell, C. B. (2005). Value Chain Responsibility: A Farewell to Arm's Length. Business and Society Review, 110 (4).

[15] Mukherji, A. and Francis, J. D. (2008). Mutual Adaption in Buyer-Supplier Relationships. Journal of Business Research, $61(2)$.

[16] Hosmer, L. (1995). Trust: The Connecting Link Between Organizational Theory and Philosophical Ethics. Academy of Management Review, 20 (2).

[17] Caldwell, C. and Clapham, S. (2003). Organizational Trustworthness: An International Perspective. Journal of Business Ethics, 47 (4).

[18] Hill, J., Eckerd, S., Wilson, D., and Greer, B. (2009). The effect of unethical behavior on trust in a buyer-supplier relationship: The mediating role of psychological contract violation. Journal of Operations Management, 27.

[19] Thompson, J. A. and Bunderson, J. S. (2003). Violations of Principle: Ideological Currency in the Psychological Contract. Academy of Management Review, 284 (4).

[20] Morgan, G. (1986). Images of Organisation. London: Sage.

[21] Hoffman, W. (1986). What is Necessary for Corporate Moral Excellence? Journal of Business Ethics, 5.

[22] Rossouw, D. (2008). Aristotle in the modern corporation: From codes of ethics to ethical culture. Phronimon, 9 (1).

[23] Brennan, S. (1999). Recent work in feminist ethics. Ethics, 109.

[24] Carroll, A. (1991). The pyramid of corporate social responsibility: Toward the moral management of organizational stakeholders. Business Horizons, 34 (4), 39-48. 
[25] Malhotra, N. K. and Birks, D. F. (2007). Marketing Research: An Applied Approach. England: Pearson Education Limited.

[26] Ring, P. S. and Van De Ven, A. H. (1994). Developmental processes of cooperative interorganizational relationships. Academy of Management Review, 19 (1).

[27] Wong, A., Tjosvold, D. and Pengzsu, Z. (2005). Supply Chain Relationships for Customer Satisfaction in China: Interdependence and Cooperative Goals. Asia Pacific Journal of Management, 22.
[28] Mohr, J. J. and Raviprect, S. S. (1995). Communication Flows in Distribution Channels: Impact on Assessments of Communication Quality and Satisfaction. Journal of Retailing. $71(4)$.

[29] Anderson, E. and Weitz, B. (1989). Determinants of continuity in conventional industrial channel Dyads. Marketing Science, 8 (4). 